\title{
Hemolysin and Serum Resistance among ESBL Producing Extraintestinal Pathogenic Escherichia coli Isolated from a Tertiary Care Hospital
}

\author{
Sharath Kumar Shetty ${ }^{1}$, D.T. Venkatesha ${ }^{1}$, Sunil P Rao ${ }^{2}$ and K. Subbannayya ${ }^{3}$ \\ ${ }^{1}$ Department of Microbiology, Hassan Institute of Medical Sciences, Hassan, Karnataka, India \\ ${ }^{2}$ Department of Microbiology, Yenepoya Medical College, Yenepoya University Mangalore, \\ Karnataka, India \\ ${ }^{3}$ Department of Microbiology, K.V.G Medical College, Sullya, Karnataka, India \\ *Corresponding author
}

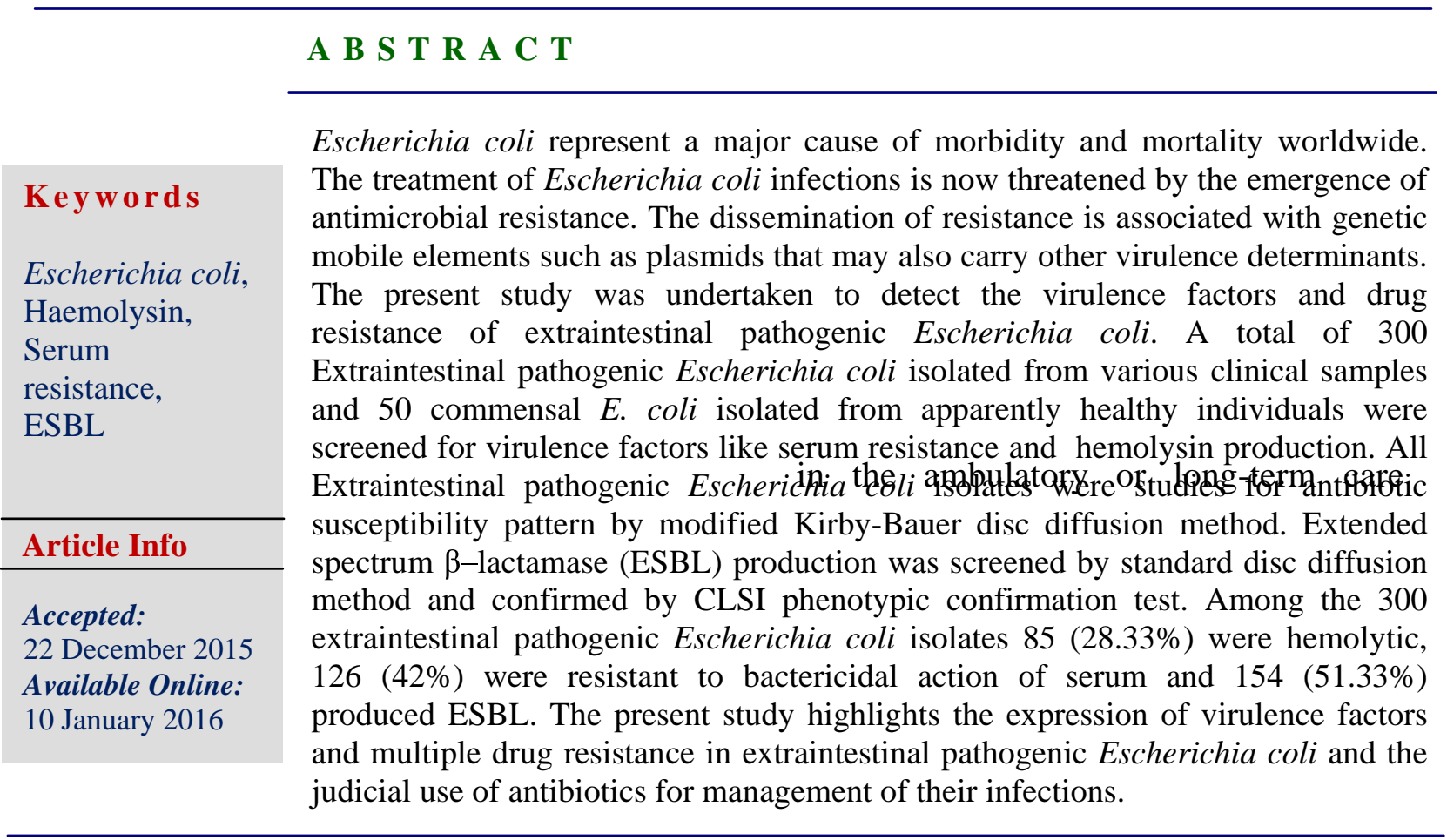

\section{Introduction}

Escherichia coli strains causing disease outside the gastrointestinal tract have been named Extraintestinal pathogenic Escherichia coli (ExPEC). Extraintestinal pathogenic Escherichia coli infections are more commonly associated with infections facilities, and in hospitals. Urinary tract is the most frequent extra intestinal site, causing $85-95 \%$ of cases of uncomplicated cystitis and pyelonephritis. Pneumonia, neonatal meningitis, surgical site infections, abdominal and pelvic infections are other 
extra intestinal types of infections (Gabriela et al., 2012, Smith et al., 2007).

The virulence potential of Escherichia coli is largely determined by the presence of specialized virulence factors (VFs) such as Haemolysin, Serum resistance, Cell Surface Hydrophobicity, Pili / Fimbriae (Type-1 fimbriae, $\mathrm{P}$ fimbriae, $\mathrm{S}$ fimbriae, PAP), $\mathrm{K}$ antigen, Somatic $\mathrm{O}$ antigen, fimbrial adhesions, Haemagglutination of erythrocytes, expression of Siderophore Aerobactin, production of Colicin $\mathrm{V}$ and Cytotoxic Necrotizing Factor (Blanc et al., 1996). The virulence traits of extraintestinal pathogenic Escherichia coli are distinct from those of intestinal pathogenic Escherichia coli and other gram negative bacilli that cause disease outside the bowel (Russo and Johnson., 2000). These virulence markers are expressed with different frequencies in different disease states ranging from asymptomatic bacteriuria to urethritis, cystitis, pyelonephritis, bacteremia and septic shock.

Production of $\beta$-lactamases are the important mechanism of drug resistance among the Gram negative bacteria. Extended spectrum $\beta$ lactamases (ESBLs) belong to group 2be of Bush's functional classification and are derived from the point mutation in original plasmid mediated TEM1 and SHV-1 $\beta$ lactamases (Bush et al., 1995). By definition, ESBL producing organisms confer resistance to penicillin, cephalosporins and monobactams. However, they cannot hydrolyze cephamycins and are inhibited by Clavulanic acid (Paterson and Bonomo., 2005, Bradford PA.2001).

The objectives of the present study were to evaluate virulence factors (serum resistance and hemolysin production) of extraintestinal pathogenic Escherichia coli with commensal strains of Escherichia coli isolated from stool samples of healthy individuals and antibacterial resistance pattern of extraintestinal pathogenic Escherichia coli with special reference to ESBL production.

\section{Materials and Methods}

This study was conducted in the department of Microbiology, Hassan Institute Medical Sciences, Hassan, over a period three years. Ethical clearance has been obtained from the institution. A total of 300 extraintestinal pathogenic Escherichia coli (test) isolated from clinical specimens and 50 commensal Escherichia coli isolated from feces of normal healthy individuals formed the study material.

Identification of the isolates was done on the basis of the colony morphology, Gram staining and the standard biochemical tests (John et al., 1994). Antibiotic sensitivity test (Kirby-Bauer disk diffusion method) was done by using Amikacin(30 $\mu \mathrm{g})$, amoxicillin-clavulanic $\operatorname{acid}(20 / 10 \mu \mathrm{g})$, ampicillin $(10 \mu \mathrm{g}), \quad$ ceftioxone $\quad(30 \mu \mathrm{g})$, cefodoxime $(10 \mu \mathrm{g}), \quad$ cefotaxime $\quad(30 \mu \mathrm{g})$, cefoxitin $(30 \mu \mathrm{g}), \quad$ ceftazidime $(30 \mu \mathrm{g})$, ceftazidime-clavulanic acid(30/10 $\mu \mathrm{g})$, ciprofloxacin $(5 \mu \mathrm{g})$, cotrimoxazole $(25 \mu \mathrm{g})$, gentamicin $(10 \mu \mathrm{g})$, imepenem $(10 \mu \mathrm{g})$,

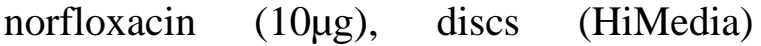
CLSI,2006).

\section{Detection of Serum Resistance}

Serum resistance was studied using fresh culture of the isolates grown at $37{ }^{\circ} \mathrm{C}$ on blood agar. The harvested cells were suspended in Hank's balanced salt solution (HBSS). Bacterial suspension $(0.05 \mathrm{~mL})$ was incubated with serum $(0.05 \mathrm{~mL})$ at $37^{\circ} \mathrm{C}$ for $180 \mathrm{~min}$. The control wells contained bacterial suspension $(0.05 \mathrm{~mL})$ and equal volume of HBSS. $10 \mu \mathrm{l}$ of samples were withdrawn at 0 minute and after 180 minutes of incubation and spread 
on blood agar plates which were then incubated at $37{ }^{\circ} \mathrm{C}$ for $18 \mathrm{~h}$ and the viable count was determined. Resistance of bacteria to serum bactericidal activity is expressed as the percentage of bacteria surviving after 180 min of incubation with serum, in relation to the original count. The bacteria were termed serum sensitive, if viable count dropped to $1 \%$ of initial value and resistant, if $>90 \%$ of organisms survived after 180 minutes (Raksha et al., 2003).

\section{Detection of Hemolysis}

Plate hemolysis test was done by using 5\% sheep blood agar for the detection of $\alpha$ hemolysin produced by Escherichia coli. Escherichia coli isolates were inoculated onto sheep blood agar and incubated overnight at $35{ }^{\circ} \mathrm{C}$. Presence of a zone of complete lysis of the erythrocytes around the colony and clearing of the medium indicates haemolysin production (Siegfried et al., 1994).

\section{Detection of ESBL Producers}

\section{CLSI Phenotypic Confirmation Test}

Escherichia coli strains resistant to Ceftazidime and Cephotaxime in antibiotic sensitivity test were subjected to phenotypic confirmation test for ESBL. In a lawn culture of the strain, Ceftazidime $(30 \mu \mathrm{g}) \mathrm{Vs}$ Ceftazidime- Clavulanic acid $(30 / 10 \mu \mathrm{g})$ and Cephotaxime $(30 \mu \mathrm{g})$ Vs CephotaximeClavulanic acid (30/10 $\mu \mathrm{g})$, discs were placed and incubated at $37^{\circ} \mathrm{C}$ overnight.

Regardless of zone diameter, a $\geq 5 \mathrm{~mm}$ increase in zone diameter of the Cephalosporin tested in combination with Clavulanic acid Vs its zone size when tested alone was taken as ESBL producer. Escherichia coli ATCC 25922 was used as the negative control and ESBL - producing organism Klebsiella pneumoniae ATCC
700603 was used as the positive control (CLSI, 2006).

\section{Results and Discussion}

Out of 300 extraintestinal pathogenic Escherichia coli 167 were from urine, 81 from pus, 26 from sputum, 12 from blood and 14 from endotracheal tubes + catheter tips. All the isolates (ExPEC and Control) were studied for hemolysin production and serum resistance. All ExPEC isolates were subjected to antibiotic sensitivity test. ESBL production was detected by screening test and phenotypic confirmation test.

Among 300 extraintestinal pathogenic Escherichia coli 126 (42\%) showed resistance to bactericidal action of serum. Highest serum resistance was seen in isolates from blood 10(83.33\%) followed by endotracheal tubes10 (71.42\%), sputum $14(53.84 \%)$, pus $39(48.14 \%)$ and urine 53 $(31.73 \%)$. Out of the 50 commensal Escherichia coli 10 (20\%) exhibited resistance to bactericidal action of serum. A previous study conducted by Sharma et al (2007), showed serum resistance in $77.4 \%$ of Escherichia coli isolated from blood which is similar to our results. In another study $32.7 \%$ of Escherichia coli were resistant to bactericidal action of serum (Raksha et al.,2003). However, Kauser et al (2009), Prachi et al (2012), Sabitha Baby et al (2014), and Siegfried et al (1994) have reported higher serum resistance in uropathogenic Escherichia coli. Bacterial resistance to killing by serum results from individual or combined effects of capsular polysaccharide and surface proteins (Taylor., 1983).

Hemolysin production is a property associated with Escherichia coli strains that infect extraintestinal sites in humans, where as it is rarely found in fecal isolates from healthy individual (Caprioli A, 1989). In the 
present study, hemolysin production was observed in $85(28.3 \%)$ extraintestinal pathogenic Escherichia coli and 7 (14\%) commensal Escherichia coli isolates respectively. Hemolysin production was highest among the isolates of endotracheal tubes + catheter tips ie, $7(50 \%)$ followed by blood 5 (41.6\%), urine $51(30.53 \%)$ pus 17
(20.98\%) and sputum 5(19.2\%).

Sharma et al (2007) reported hemolysin production in $64.2 \%$ of Escherichia coli isolated from blood. Raksha et al (2003), Johnson (1991) and Fakrunddin et al (2013) have reported highest hemolysin production among urinary isolates.

Table.1 Virulence Markers of Extra Intestinal Pathogenic and Commensal Escherichia coli Isolates

\begin{tabular}{|c|c|c|c|c|c|c|c|c|}
\hline $\begin{array}{l}\text { Virulence } \\
\text { factors }\end{array}$ & $\begin{array}{l}\text { Urine } \\
\text { (167) }\end{array}$ & $\begin{array}{l}\text { Pus } \\
(81)\end{array}$ & $\begin{array}{l}\text { Sputum } \\
(26)\end{array}$ & $\begin{array}{l}\text { Blood } \\
\text { (12) }\end{array}$ & $\begin{array}{l}\text { catheter } \\
\text { tips(14) }\end{array}$ & $\begin{array}{l}\text { Total } \\
(300)\end{array}$ & \begin{tabular}{|l} 
Control \\
$(50)$
\end{tabular} & $\mathrm{p}$ \\
\hline $\begin{array}{l}\text { Serum } \\
\text { resistance }\end{array}$ & $\begin{array}{l}53 \\
(31.73 \%)\end{array}$ & $\begin{array}{l}39 \\
(48.1 \%)\end{array}$ & $\begin{array}{l}14 \\
(53.8 \%)\end{array}$ & $\begin{array}{l}10 \\
(83.3 \%)\end{array}$ & $\begin{array}{l}10 \\
(71.4 \%)\end{array}$ & $\begin{array}{l}126 \\
(42 \%)\end{array}$ & \begin{tabular}{|l|}
10 \\
$(20 \%)$
\end{tabular} & 0.05 \\
\hline Haemolysin & $\begin{array}{l}51 \\
(30.53 \%)\end{array}$ & $\begin{array}{l}17 \\
(20.98 \%)\end{array}$ & $\begin{array}{l}05 \\
(19.2 \%)\end{array}$ & $\begin{array}{l}05 \\
(41.6 \%)\end{array}$ & $\begin{array}{l}07 \\
(50 \%)\end{array}$ & $\begin{array}{l}85 \\
(28.3 \%)\end{array}$ & $\begin{array}{l}07 \\
(14 \%)\end{array}$ & $<0.05$ \\
\hline
\end{tabular}

Table.2 ESBL Production in Extra Intestinal Pathogenic Escherichia coli

\begin{tabular}{|l|c|c|c|}
\hline \multicolumn{1}{|c|}{ Sample } & Number of isolates & ESBL positive & Percentage \\
\hline Urine & 167 & 86 & 51.49 \\
\hline Pus & 81 & 38 & 46.91 \\
\hline Blood & 12 & 7 & 58.33 \\
\hline Sputum & 26 & 11 & 42.3 \\
\hline Catheter tips & 14 & 12 & 85.71 \\
\hline Total & 300 & 154 & 51.33 \\
\hline
\end{tabular}

Table.3 ESBL Production by Serum Resistant and Serum Sensitive Extraintestinal Pathogenic Escherichia coli

\begin{tabular}{|c|c|c|c|c|c|c|}
\hline \multicolumn{3}{|c|}{ Serum resistant(126) } & \multicolumn{3}{c|}{ Serum sensitive (174) } & \multirow{2}{*}{$\mathrm{p}$} \\
\cline { 1 - 5 } $\begin{array}{c}\text { ESBL } \\
\text { Positive }\end{array}$ & $\begin{array}{c}\text { ESBL } \\
\text { Negative }\end{array}$ & Percentage & $\begin{array}{c}\text { ESBL } \\
\text { Positive }\end{array}$ & $\begin{array}{c}\text { ESBL } \\
\text { Negative }\end{array}$ & Percentage & \\
\hline 65 & 61 & 51.58 & 89 & 85 & 51.14 & $>0.05$ \\
\hline
\end{tabular}

Table.4 ESBL Production by Haemolytic and Non Haemolytic Extraintestinal Pathogenic Escherichia coli

\begin{tabular}{|c|c|c|c|c|c|c|}
\hline \multicolumn{3}{|c|}{ Haemolytic(85) } & \multicolumn{3}{|c|}{ Non Haemolytic(215) } & \multirow{2}{*}{$\mathrm{p}$} \\
\hline $\begin{array}{c}\text { ESBL } \\
\text { Positive }\end{array}$ & $\begin{array}{c}\text { ESBL } \\
\text { Negative }\end{array}$ & Percentage & $\begin{array}{c}\text { ESBL } \\
\text { Positive }\end{array}$ & $\begin{array}{c}\text { ESBL } \\
\text { Negative }\end{array}$ & Percentage & \\
\hline 52 & 33 & 61.17 & 102 & 113 & 47.44 & $<0.05$ \\
\hline
\end{tabular}


Antibiotic susceptibility pattern was studied for all isolates of extra intestinal pathogenic Escherichia coli. Resistance was observed to commonly used antibiotics such as ampicillin, ciprofloxacin, co-trimoxazole, cefotaxime, gentamicin, nalidixic acid, ceftrioxone and ceftazidime where as all the strains were susceptible to Imepenem. In the present study we found that $76.9 \%$ isolates were resistant to ampicillin. These results were consistent with the previous studies on drug resistance in Escherichia coli (Gupta et al., 1999, Suman and Bhat GK 2001). The greater prevalence of resistance to common antibiotics has also been reported by other workers (chitins et al., 2003 and Weiner et al 1993). Several bacteria, including Escherichia coli, construct a multiple-antibiotic-resistance efflux pump that provides the bacterium with resistance to multiple types of antibiotics, including erythromycin, tetracycline, ampicillin and nalidixic acid. This pump expels the antibiotic from the cell's cytoplasm, helping to maintain the intracellular levels below a lethal concentration. (Oethinger M.et al., 1988).The higher rates of multidrug resistance in Escherichia coli may be related to the dissemination of antibiotic resistance among hospital isolates of Escherichia coli.

Escherichia coli is the most common ESBL producing Gram negative bacteria isolated from different clinical samples followed by Klebsiella. The present study detected $51.3 \%$ of ESBL production among ExPEC and results of the present study correlate with other studies from Karnataka. (Ananthakrishna et al., 2000, Nair T Bhaskaran et al., 2011). In the present study, the highest percentage of ESBLs was observed among inpatients (77.2\%). In 2006, the Antimicrobial Availability Task
Force of the Infectious Diseases Society of America listed ESBL-producing Enterobacteriaceae (Klebsiella species and Escherichia coli) as one of six problematic drug-resistant pathogens and suggested an urgent need for newer and more effective therapeutics (Talbot et al., 2006). The high rate of ESBL production by extra intestinal pathogenic Escherichia coli may be due to the selective pressure imposed by extensive use of antimicrobials and indiscriminate use of cephalosporins. In infections with ESBL producing strains, a slight increase in MICs of oxyimino-cephalosporins has been reported to be sufficient to cause treatment failure. The availability of antibiotics without a prescription, their widespread use by the general public often with suboptimal dosing and duration of therapy, contribute to the emergence of this problem. The judicious use of antibiotics, good antibiotic policy, periodic surveillance of antibiotic resistance patterns and accurate detection and reporting of ESBL production by pathogenic bacteria are needed to limit the emergence and spread of antibiotic resistance in bacteria.

\section{Acknowledgement}

We are extremely thankful to Dr.Ravikumar B.C, Director HIMS Hassan, Karnataka for providing the necessary facilities during the research work.

\section{References}

Anathakrishan, AN., Kanungo, R., Kumar, A., Badrinath, S. 2000.Detection of extended spectrum b-lactamase producers among surgical wound infections and burn patients in JIPMER. Indian J Med Microbiol. 18:160-5.

Baby, Sabitha, Vimal Kumar Karnaker, and 
R. K. Geetha. 2014. Serum Bactericidal Resistance in Uropathogenic E. coli. Int. J. Curr. Microbiol. App. Sci 3(8) 823-828.

Blanc, M., Blanco, JE., Abalia, L., Alonso, MP., Blanco, J.1996. Virulence factors and $\mathrm{O}$ groups of Escherichia coli isolates from patients with acute pyelonephritis, cystitis and asymptomatic bacteriuria. Eur J Epidemiol. 12:191-198.

Bradford, PA. 2001. Extended spectrum $\beta$ lactamases in $21^{\text {st }}$ century: Characterization, epidemiology and detection of this important resistance threat. Clin Microbiol Rev 14:93351.

Bush, K., Jacoby GA., Medeiros, AA.1995. A functional classification scheme for $\beta$ - lactamases and its correlation with molecular structure. Antimicrob.Agents Chemother. 39:1211-33.

Caprioli, A., Falbo, V.,Ruggeri, FM.,Minelli, F.,OrskovI, Donelli, G.1989.relationship between Cytotoxic necrotizing factor production and serotype in hemolytic E.coli.J Clin Microbiol.27,758-761.

Chitnis, SV., Chitris, V., Sharma, N., Chitnis, DS. 2003. Current status of drug resistance among gram negative bacilli isolated from admitted cases in a tertiary care centre. J Assoc Physicians India. 51:28-31.

Clinical and Laboratory standards.2006. Performance standards for antimicrobial susceptibility testing; 16th Informational Supplement, Clinical and Laboratory Standards Institute; M100- S 16 CLSI, USA, Wayne. PA.

Fakruddin, M.,Reaz, M., Mazumdar, Abhijit., C, Shanewaj. KBN.2013.A preliminary study on virulence factors and antimicrobial resistance in extraintestinal pathogenic Escherichia coli (ExPEC) in Bangladesh.Indian J Med Res.137 ,988-990.

Gabriela, J., da Silva., Nuno Mendonca. 2012. Association between antimicrobial resistance and virulence in Escherichia coli, Virulence. 3(1): 18-28.

Gupta, K., Scholes, D., Stamm, WE. 1999. Increasing prevalence of antimicrobial resistance among uropathogens causing acute uncomplicated cystitis in women. JAMA 281:736-8.

John, GH., Noel, RK,,Peter, HA.,Sneath,J., Stanley, T.1994. Willams. Facultative anaerobic Gram negative rods. In: Bergey's Manual of Determinative Bacteriology, 9thed. William R.Hensyl,Editor (Lippincott Williams \& Wilkins USA):23

Johnson, JR .1991. Virulence factors in Escherichia coli urinary tract infection. Clinical Micro Review.4(1):80-128.

Kausar,Y.,Chunchanur, $\quad$ S., $\quad$ Nadagir S,.Halesh,LH.,Chandrasekhar,MR.20 09 . The virulence factors, serotypes and the antimicrobial susceptibility pattern of Escherichia coli in urinary tract infections. Al Ameen J Med Sci. 2.1.:47-51.

Nair,TB., Bhat KG., Shantaram, M.2013. Invitro biofilm production and virulence factors of uropathogenic Escherichia coli.Int J Pharm Bio Sci.4(1): (B) 951-956.

Oethinger, M., I. Podglajen, W.V. Kern and S.T. Levy, 1988. Overexpression of the marA and soxS regulatory gene in clinical topoisomerase mutants of Escherichia coli. Antimicrob Agent Chemother. 42: 2089-2094.

Paterson, DL.,Bonomo,RA.2005. Extended -spectrum $\beta$-lactamases clinical 
update. Clin Microbiol Rev. 18:65786.Prachi, S., Chandan, S., Ssaileela, K.2012. Pattern of Serum Resistance in Uropathogenic Escherechia Coli. Int J Pharm Bio Scie 3(2):43-48.

Raksha, R., Srinivasa, H., Macaden, RS.2003. Occurrence and characterization of uropathogenic Escherichia coli in urinary tract infections. Indian J Med Microbiol. $21: 102-7$.

Russo, TA., Johnson, JR. 2000. Proposal for a new inclusive designation for extraintestinal pathogenic isolates of Escherichia coli:ExPEC. J Infect Dis. 181:1753-1754.

Sharma, S., Bhat, G K., Shenoy, S. 2007.Virulence factors and drug resistance in Escherichia coli isolated from extraintestinal infections. Indian J Med Microbiol. 25:369-73.

Siegfried, L., Kmetova, M.,Puzova, H. Molokacova, M,Filka,J. 1994. Virulence associated factors in E.coli strains isolated from children with urinary tract infections. J Med Microbiol. 41:127-32.
Smith, JL., Fratamico, PM., Gunther, NW. 2007. Extraintestinal pathogenic Escherichia coli. Food borne Pathog Dis. 4:134-63.

Suman, E., Bhat, GK. 2001. Urinary tract infection in children due to drug resistant bacteria: A study from South India. J Trop Pediatr.47:3745.

Talbot, G H., Bradley, J., Edwards, JE., Jr, Gilbert, D., Scheld, M., Bartlett, JG. 2006. Bad bugs need drugs: an update on the development pipeline from the Antimicrobial Availability Task Force of the Infectious Diseases Society of America. Clin Infect Dis. 42, 657-668.

Taylor, PW.1983. Bactericidal and bacteriolytic activity of serum against gram negative bacteria. Microbiol Rev.3; 47:46-83.

Wiener, J., Quinn, JP., Bradford, PA., Goering, RV., Nathan C,, Bush. K., et al . 1999. Multiple antibiotic resistant Klebsiella and Escherichia coli in a nursing home. JAMA. 281:517-23.

\section{How to cite this article:}

Sharath Kumar Shetty, D.T. Venkatesha, Sunil P Rao and Subbannayya, K. 2016. Hemolysin and Serum Resistance among ESBL Producing Extraintestinal Pathogenic Escherichia coli Isolated from a Tertiary Care Hospital. Int.J.Curr.Microbiol.App.Sci.5(1): 71-77. doi: inttp:///dx.doi.org/10.20546/jijomas.2016.501.006 